\title{
PERBEDAAN RASIO PROFITABILITAS PADA PERUSAHAAN- PERUSAHAAN SEKTOR PERTANIAN DI BURSA EFEK INDONESIA
}

\author{
Oleh: \\ Ninin Non Ayu Salmah \\ Universitas PGRI Palembang \\ Jalan Jenderal Ahmad Yani Lorong Gotong Royong Palembang
}

\begin{abstract}
This study aims to determine the difference in the ratio of profitability as a measure of financial performance between companies incorporated in the Agricultural Sector on the Indonesia Stock Exchange with the hypothesis test analysis technique difference of more than two averages. Research population are companies listed on Indonesia Stock Exchange Agricultural Sector. Research sample is PT. Bisi International Tbk, PT. Dharma Samudera Fishing Industries Tbk and PT. Astra Agro Lestari Tbk. The highest average ratio is obtained by PT. Astra Agro Lestari Tbk such as return on asset ratio equal to $11,8200 \%$, return on equity ratio equal to $17,1180 \%$ as well net profit margin ratio equal to $14,6380 \%$. Hypothesis test of difference of more than two average concluded that the average return on asset ratio on companies incorporated in the Agricultural Sector on the Indonesia Stock Exchange differs significantly, the average return on equity ratio on companies incorporated in the Agricultural Sector on the Indonesia Stock Exchange differs significantly and the average net profit margin ratio on companies incorporated in the Agricultural Sector on the Indonesia Stock Exchange differs significantly.
\end{abstract}

Keywords: profitability ratio, return on asset, return on equity, net profit margin

\section{PENDAHULUAN}

Penggunaan instrumen investasi di pasar modal di Indonesia melalui Bursa Efek Indonesia telah berkembang pesat karena kemajuan teknologi informasi dan komunikasi. Bursa Efek Indonesia telah menyediakan sarana dan informasi yang cukup memadai bagi pelaku pasar modal, baik emiten, investor, pemerintah maupun pihak-pihak lain yang turut berperan dalam membentuk mekanisme pasar modal.

Perkembangan instrumen investasi terutama saham telah menunjukkan perkembangan berarti dengan terdaftarnya lebih dari 550 saham di Bursa efek Indonesia pada tahun 2016 yang diklasifikasikan dalam berbagai sektor. Salah satu sektor pada Bursa Efek Indonesia adalah sektor pertanian. Perusahaan yang bergerak dalam sektor pertanian memiliki prospek yang cerah karena sektor pertanian merupakan sektor yang 
tangguh dalam perekonomian. Sektor pertanian memiliki keunggulan absolut dalam sumber daya alam sehingga dengan penerapan good corporate governance dan dukungan regulasi memungkinkan perusahaan sektor pertanian menjadi perusahaan terdepan dalam menyumbang peningkatan pertumbuhan perekonomian.

Penilaian saham oleh investor untuk menjadi bagian instrumen investasi dalam portofolio berdasarkan berbagai analisis sehingga akan membentuk preferensi terhadap suatu saham. Analisis fundamental digunakan investor terhadap saham berdasarkan berbagai informasi mengenai perusahaan dan lingkungannya diantaranya informasi berdasarkan laporan keuangan sebagai ukuran kinerja dan proyeksi keuangan perusahaan. Husnan (2009:307) menjelaskanbahwa analisis fundamental mencoba memperkirakan harga saham dimasa yang akan datang dengan mengestimasi nilai faktorfaktor fundamental yang mempengaruhi harga saham dimasa yang akan datang dan menerapkan hubungan variabel-variabel tersebut sehingga diperoleh taksiran harga saham.Penggunaan analisis fundamental membantu investor dalam keputusan jual dan beli saham.

Tingkat profitabilitas perusahaan merupakan salah satu aspek yang menjadi penilaian investor dalam analisis fundamental karena memperlihatkan perolehan dan proyeksi laba perusahaan. Perusahaan yang menghasilkan laba secara berkelanjutan dan menunjukkan perkembangan positif mengindikasikan perusahaan yang sehat. Semakin baik tingkat profitabilitas suatu perusahaan maka semakin meningkatkan kepercayaan investor sehingga semakin tinggi keinginan investor untuk menanamkan modalnya kepada perusahaan tersebut.

. Kinerja keuangan diamati investor sebagai bagian dari penilaian fundamental perusahaan. Jumingan (2011:239) mendefinisikan kinerja keuangan sebagai gambaran kondisi keuangan pada suatu periode tertentu baik menyangkut aspek penghimpunan dana maupun penyaluran dana yang biasanya diukur dengan indikator kecukupan modal, likuiditas dan profitabilitas. Rhamadana dan Triyonowati (2016) mengemukakan bahwa adanya analisis keuangan selain dapat menilai kinerja keuangan perusahaan, aspek penting dapat memberikan gambaran mengenai kondisi kesehatan keuangan tersebut, maka pihak manajemen dan para investor dapat mengetahui baik atau tidaknya kondisi kesehatan suatu perusahaan 
Kinerja keuangan dapat direpresentasikan dengan rasio keuangan. Laporan keuangan perusahaan menyediakan informasi mengenai profitabilitas yang diperoleh perusahaan dengan berbagai rasio keuangan. Zulkifli dan Wujayanti (2014) mengemukakan bahwa untuk mengukur suatu kinerja perlu melibatkan laporan keuangan, karena dalam laporan keuangan inilah segala hasil kebijakan manajemen terangkum dan terdokumentasisecara memadai dalam bentuk informasikeuangan.

Rasio keuangan diantaranya adalah rasio return on asset (ROA) yang memberikan ukuran profitabilitas perusahaan dan menunjukkan efektivitas manajemen dalam memperoleh laba dengan menggunakan asetdalam perusahaan, rasio return on equity (ROE) yang memberikan ukuran profitabilitas perusahaan dan menunjukkan efisiensi manajemen dalam memperoleh laba dengan menggunakan modal sendiri serta rasio net profit margin (NPM) yangmemberikan ukuran profitabilitas perusahaan dan menunjukkan produktivitas manajemen dalam menghasilkan laba melalui penjualan.

Tujuan penelitian ini adalah untuk mengetahui ada tidaknya perbedaan tingkat profitabilitas antara perusahaan-perusahaan yang tergabung dalam Sektor Pertanian di Bursa Efek Indonesia. Hipotesis yang diajukan dalam penelitian ini adalah 1)rata-rata rasio return on asset pada perusahaan-perusahaan yang tergabung dalam Sektor Pertanian di Bursa Efek Indonesia berbeda secara signifikan 2)rata-rata rasio return on equity pada perusahaan-perusahaan yang tergabung dalam Sektor Pertanian di Bursa Efek Indonesia berbeda secara signifikan 3)rata-rata rasio net profit margin pada perusahaan-perusahaan yang tergabung dalam Sektor Pertanian di Bursa Efek Indonesia berbeda secara signifikan

\section{KERANGKA TEORITIS}

\section{Analisis Fundamental}

Salah satu pendekatan dalam menganalisis dan memilih saham adalah dengan analisis fundamental yang mengidentifikasi, menghubungkan dan menginterpretasikan faktor-faktor fundamental dalam perusahaan, diantaranya aset, modal, penjualan dan laba. Martalena dan Malinda (2011:47) menjelaskan bahwa analisis fundamental merupakan analisis yang mempraktikkan harga saham di masa yang akan datang dengan 
mengestimasi nilai faktor-faktor fundamental yang memengaruhi harga saham di masa yang akan datang dan menerapkan hubungan variabel-variabel tersebut.

\section{Kinerja Keuangan}

Kesehatan keuangan perusahaan dapat diamati dari kinerja keuangan. Hasil yang dicapai manajemen dalam kinerja keuangan mencerminkan pengelolaan keuangan yang efektif. Sebagai bidang fungsional efektivitas pengelolaan keuangan perusahaan berkaitan dengan bidang-bidang fungsional lainnya dalam perusahaan. Rudianto (2013, 189) mendefinisikan kinerja keuangan sebagai hasil atau prestasi yang telah dicapai oleh manajemen perusahaan dalam menjalankan fungsinya mengelola aset perusahaan secara efektif selama periode tertentu.

\section{Laporan Keuangan}

Manajemen keuangan membutuhkan laporan keuangan agar dapat mengetahui kondisi keuangan perusahaan termasuk kinerja keuangan perusahaan. Laporan keuangan merupakan sumber informasi yang kemudian diolah dan diinterpretasikan sebagai capaian kinerja keuangan perusahaan. Sutrisno (2007:9) menjelaskan laporan keuangan merupakan hasil akhir dari proses akuntansi yang meliputi dua laporan utama, yakni neraca dan laporan laba rugi.

\section{Rasio Keuangan}

Rasio keuangan berperan dalam mengukur kinerja keuangan sehingga dapat diketahui perbandingan kinerja keuangan dari waktu ke waktu, dengan kinerja perusahaan lain atau perubahan yang terjadi yang menginformasikan adanya perkembangan atau penurunan. Fahmi(2011 :106) mendefinisikan rasio keuangan sebagai hasil yang di peroleh dari perbandingan jumlah, dari satu jumlah dengan jumlah lainnya sedangkan Harahap (2011:297) mendefinisikan rasio keuangan sebagai angka yang diperoleh dari hasil perbandingan dari satu pos laporan keuangan dengan pos lainnya yang mempunyai hubungan yang relevan dan signifikan. 


\section{Rasio Profitabilitas}

Perolehan laba perusahaan merupakan pencerminan kondisi keuangan perusahaan yang dinyatakan sebagai pencapaian kinerja keuangan perusahaan baik efisiensi pembiayaan maupun efektivitas keputusan investasi. Sartono (2010:122) mendefinisikan rasio profitabilitas sebagai kemampuan perusahaan memperoleh laba dalam hubungannya dengan penjualan, total aktiva maupun modal sendiri. Manfaat rasio profitabilitas menurut Kasmir (2012:197) adalah 1)mengetahui besarnya laba yang diperoleh perusahaan dalam satu periode 2)mengetahui posisi laba perusahaan tahun sebelumnya dengan tahun sekarang 3)mengetahui perkembangan laba dari waktu ke waktu 4)mengetahui besarnya laba bersih sesudah pajak dengan modal sendiri 5)mengetahui produktivitas dari seluruh dana perusahaan yang digunakan baik modal pinjaman maupun modal sendiri.

\section{Return on Asset (ROA)}

Prihadi (2008: 68) menjelaskan rasio return on asset mengukur tingkat laba terhadap aktiva yang digunakan dalam menghasilkan laba tersebut. Rumus rasio return on asset adalah $\mathrm{ROA}=($ Laba Bersih Sesudah Pajak/Total Aktiva $) \times 100 \%$. Laba bersih sesudah pajak dan total aset merupakan faktor yang mempengaruhi return on asset. Nilai rasio return on asset yang tinggi mencerminkan manajemen mampu mengelola seluruh aset perusahaan dalam menghasilkan laba.

\section{Return on Equity (ROE)}

Kasmir (2012:204) menjelaskan rasio return on equity merupakan rasio untuk mengukur laba bersih sesudah pajak denganmodal sendiri. Rumus rasio return on equityadalah $\mathrm{ROE}=($ Laba Bersih Sesudah Pajak/Modal Sendiri $) \times 100 \%$. Laba bersih sesudah pajak dan modal sendiri merupakan faktor yang mempengaruhi return on equity. Nilai rasio return on equity yang tinggi mencerminkan manajemen mampu mengelola modal sendiri dalam menghasilkan laba. 


\section{Net Profit Margin (NPM)}

Munawir (2010: 89) menjelaskan rasio net profit margin mengukur tingkat keuntungan yang dapat dicapai oleh perusahaan dihubungkan dengan penjualannya. Rumus rasio net profit marginadalah NPM = (Laba Bersih Sesudah Pajak/Penjualan Bersih) x 100\%. Laba bersih sesudah pajak dan penjualan bersih merupakan faktor yang mempengaruhi net profit margin. Nilai rasio net profit margin yang tinggi mencerminkan manajemen mampu mengelola penjualan dalam menghasilkan laba.

\section{METODE PENELITIAN}

\section{Populasi dan Sampel}

Penelitian ini merupakan penelitiankomparatif yang bertujuan membandingkan lebih dari satu kelompok sampel pada satu variabel. Periode pengamatan selama 5 tahun yaitu tahun 2012 sampai dengan tahun 2016.

Populasi penelitian ini adalah perusahaan-perusahaan yang tercatat pada Bursa Efek Indonesia dan tergabung dalam Sektor Pertanian yang berjumlah 15 perusahaan. Perusahaan tersebut adalah PT. Bisi International Tbk, PT. Astra Agro Lestari Tbk, PT. Austindo Nusantara Jaya Tbk, PT. Eagle High Plantation Tbk, PT. Dharma Satya Nusantara Tbk, PT. Golden Plantation Tbk, PT. Gozco Plantation Tbk, PT. Jaya Agra Wattie Tbk, PT. PP London Sumatera Indonesia Tbk, PT. Multi Agro Gemilang Plantation Tbk, PT. Provident Agro Tbk, PT. Central Proteinaprima Tbk, PT. Dharma Samudera Fishing Tbk, PT. Inti Agro Resources Tbk dan PT. Bumi Teknokultura Unggul Tbk.

Teknik pengambilan sampel dengan purposive sampling yang menetapkan anggota sampel berdasarkan kriteria tertentu.. Kriteria perusahaan yang menjadi anggota sampel 1)perusahaan yang tercatat pada Bursa Efek Indonesia dan tergabung dalam Sektor Pertanian Bursa Efek Indonesia 2)perusahaan mempublikasikan laporan keuangan secara berkala setiap tahunnya 3)perusahaan memiliki kelengkapan data sesuai dengan kebutuhan penelitian 4)perusahaan tidak melakukan corporate action dan tidak pernah delisting atau relisting selama periode pengamatan 5)rasio profitabilitas perusahaan tidak pernah bertanda negatif selama periode pengamatan. Berdasarkan kriteria tersebut diperoleh sampel sebanyak 3 perusahaan yaituPT. Bisi International Tbk dengan kode 
saham BISI, PT. Dharma Samudera Fishing Industries Tbkdengan kode saham DSFI sertaPT. Astra Agro Lestari Tbk dengan kode saham AALI dan diperoleh rasio return on asset (ROA), return on equity(ROE) dan net profit margin(NPM)sebagai variabel penelitian.

\section{Sumber dan Teknik Pengumpulan Data}

Data penelitian ini bersumber pada data sekunder dengan teknik pengumpulan data dokumenter. Data yang dibutuhkan adalah data tahunan selama periode pengamatan yang diperoleh dari laporan keuangan perusahaan dan dipublikasikan oleh Bursa Efek Indonesia pada laman http://www.idx.co.id.

\section{Variabel Penelitian}

Variabel dalam penelitian adalah tingkat profitabilitas yang meliputi rasio return on asset, return on equity dan net profit margin. Definisi operasionalisasi variabel adalah 1)rasio return on asset, adalah rasio yang menunjukkan kemampuan perusahaan dalam menghasilkan laba dengan menggunakan keseluruhan aset yang ada dalam perusahaan 2)rasio return on equity, adalah kemampuan perusahaan dalam dalam menghasilkan laba dengan menggunakan modal sendiri 3)net profit margin, adalah kemampuan perusahaan dalam menghasilkan laba pada setiap penjualan yang dilakukan.

\section{Teknik dan Alat Analisis Data}

Teknik analisis data adalah deskriptif dan kuantitatif. Analisis deskriptif digunakan untuk memaparkan, menjelaskan dan menganalisis data dan hasil penelitian.

Teknik kuantitatif yang digunakan untuk melakukan pengujian hipotesis dengan uji perbedaan lebih dari dua rata-rata. Tahapan pengujian hipotesis adalah 1)menghitung tingkat profitabilitas dan memilih sampel berdasarkan kriteria yang telah ditentukan 2)melakukan uji normalitas dengan uji Saphiro-Wilk dengan batas penerimaan data berdistribusi normal adalah jika nilai Sig.lebih besar dari $\alpha=0,053$ )menentukan formulasi hipotesis 3)menentukan level signifikan pada $\alpha=0,05$ 4)melakukan uji hipotesis a)jika data berdistribusi normal maka dilakukan uji homogenitas varian dengan Levene's test dan batas penerimaan kesamaan varian lebih besar dari $\alpha=0,05$ dan jika dihasilkan varian yang sama maka pengujian hipotesis dilanjutkan dengan uji One Way Anova dan batas 
penerimaan hipotesis nol adalah lebih besar dari $\alpha=0,05$ tetapi jika ditemukan varian yang tidak sama maka pengujian hipotesis dilanjutkan dengan uji Brown-Forsythe dan batas penerimaan hipotesis nol lebih besar dari $\alpha=0,05$ b)jika data tidak berdistribusi normal maka dilakukan uji statistik non parametrik Kruskal-Wallis dengan batas penerimaan hipotesis nol lebih besar dari $\alpha=0,05$ 5) menarik kesimpulan dengan menerima atau menolak hipotesis nol.

Alat analisis data adalah teknik statistik inferensial. Perhitungan dan pengolahan data dalam penelitian ini menggunakan software SPSS (Statistical Program and Service Solution) Version 20.0 for Windows.

\section{HASIL DAN PEMBAHASAN \\ Deskripsi Statistik Variabel Penelitian}

Deskripsi statistik digunakan untuk mengetahui nilai minimum, maksimum, ratarata dan standar deviasi sampel penelitian. Nilai mean adalah nilai yang mewakili keseluruhan data sedangkan nilai standar deviasi menunjukkan variasi data. Berikut ini disajikan hasil deskripsi statistik variabel penelitian dengan sampel PT. Dharma Samudera Fishing Industries Tbk (DSFI), PT. Astra Agro Lestari Tbk (AALI) dan PT. Bisi International Tbk (BISI) serta hasil deskripsi statistik seluruh sampel (ALL).

Tabel berikut ini menyajikan deskripsi statistik rasio return on asset sampel penelitian selama periode pengamatan.

\section{Tabel 1. Deskripsi Statistik Return on Asset}

\begin{tabular}{crrrr}
\hline & Minimum & Maksimum & \multicolumn{1}{c}{ Mean } & St. Deviation \\
\hline ROA DSFI & 1,24 & 4,60 & 3,7580 & 1,42071 \\
ROA AALI & 3,23 & 20,29 & 11,8200 & 6,34868 \\
ROA BISI & 7,42 & 12,33 & 9,4400 & 1,97038 \\
ROA ALL & 1,24 & 20,29 & 8,3393 & 5,04552 \\
\hline
\end{tabular}

Selama periode pengamatan, rata-rata rasio return on asset tertinggi dan nilai maksimum tertinggi diperoleh PT. Astra Agro Lestari Tbk sebesar 11,8200\% dan 20,29\% sedangkan nilai minimum terendah diperoleh PT. Dharma Samudera Fishing Industries Tbk sebesar 1,24\%, dengan demikian tingkat profitabilitas berdasarkan rasio return on asset PT.Astra Agro Lestari Tbk adalah yang paling baik dibandingkan perusahaan lainnya. Rata-rata rasio return on assetPT. Astra Agro Lestari Tbk sebesar 
11,8200\% memberikan arti setiap Rp 1,00 aktiva dapat menghasilkan laba sebesar Rp 0,1182 .

Rata-rata industri rasio return on asset berdasarkan sampel penelitian yang menjadi patokan pencapaian kinerja perusahaan sebesar $8,3393 \%$. Besarnya rasio tersebut adalah lebih tinggi dari rasio return on asset PT. Dharma Samudera Fishing Industries Tbk tetapi lebih rendah dari rasio return on asset PT. Astra Agro Lestari Tbk dan PT. Bisi International Tbk.

Standar deviasi rasio return on assetPT. Astra Agro Lestari Tbk $(6,34868 \%)$ lebih tinggi dari perusahaan lainnya bahkan lebih tinggi dari standar deviasi industri $(5,04552 \%)$. Dengan demikian rasio return on asset PT. Astra Agro Lestari Tbk lebih bervariasi dari rasio perusahaan lainnya dan industri.

Tabel berikut ini menyajikan deskripsi statistik rasio return on equity sampel penelitian selama periode pengamatan.

Tabel 2. Deskripsi Statistik Return on Equity

\begin{tabular}{crrrr}
\hline & Minimum & Maximum & \multicolumn{1}{c}{ Mean } & Standar Deviasi \\
\hline ROE DSFI & 5,95 & 11,26 & 8,7600 & 3,59584 \\
ROE AALI & 8,61 & 26,91 & 17,1180 & 8,27752 \\
ROE BISI & 2,45 & 14,54 & 10,9580 & 2,35960 \\
ROE ALL & 2,45 & 26,91 & 12,2787 & 6,18629 \\
\hline
\end{tabular}

Selama periode pengamatan, rata-rata rasio return on equity tertinggi dan nilai maksimum tertinggi diperoleh PT. Astra Agro Lestari Tbk sebesar 17,1180\% dan 26,91\% sedangkan nilai minimum terendah diperoleh PT. Bisi International Tbk sebesar $2,45 \%$. dengan demikian tingkat profitabilitas berdasarkan rasio return on equity PT.Astra Agro Lestari Tbk adalah yang paling baik dibandingkan perusahaan lainnya. Rata-rata rasio return on equity PT. Astra Agro Lestari Tbk sebesar 17,1180\% memberikan arti setiap $\mathrm{Rp}$ 1,00 modal sendiri dapat menghasilkan laba sebesar Rp 0,17118 .

Rata-rata industri rasio return on equity berdasarkan sampel penelitian yang menjadi patokan pencapaian kinerja perusahaan sebesar 12,2787\%. Besarnya rasio tersebut adalah lebih tinggi dari rasio return on equity PT. Dharma Samudera Fishing Industries Tbk dan PT. Bisi International Tbk tetapi lebih rendah dari rasio return on equity PT. Astra Agro Lestari Tbk. 
Standar deviasi rasio return on equityPT. Astra Agro Lestari Tbk $(8,27752 \%)$ lebih tinggi dari perusahaan lainnya bahkan lebih tinggi dari standar deviasi industri $(6,18629 \%)$. Dengan demikian, rasio return on equity PT. Astra Agro Lestari Tbk lebih bervariasi darirasio perusahaan lainnya dan industri.

Tabel berikut ini menyajikan deskripsi statistik rasio net profit margin sampel penelitian pada periode pengamatan.

Tabel 3. Deskripsi Statistik Net Profit Margin

\begin{tabular}{lrrrr}
\hline & \multicolumn{1}{c}{ Minimum } & Maximum & \multicolumn{1}{c}{ Mean } & Standar Deviasi \\
\hline NPM DSFI & 0,83 & 3,38 & 2,4640 & 0,98399 \\
NPM AALI & 5,33 & 21,79 & 14,6380 & 5,91873 \\
NPM BISI & 12,03 & 19,58 & 15,8400 & 3,08439 \\
NPM ALL & 0,83 & 21,79 & 10,9807 & 7,21935 \\
\hline
\end{tabular}

Selama periode pengamatan, rata-rata rasio net profit margin tertinggi dan nilai maksimum tertinggi diperoleh PT. Astra Agro Lestari Tbk sebesar 14,6380\% dan 21,79\% sedangkan nilai minimum terendah diperoleh PT. Dharma Samudera Fishing Industries Tbk sebesar $0,83 \%$, dengan demikian tingkat profitabilitas berdasarkan rasio net profit margin PT.Astra Agro Lestari Tbk adalah yang paling baik dibandingkan perusahaan lainnya. Rata-rata rasio net profit margin PT. Astra Agro Lestari Tbk sebesar 14,6380\% berarti setiap Rp 1,00 penjualan dapat menghasilkan laba sebesar Rp 0,14638.

Rata-rata industri rasio net profit margin berdasarkan sampel penelitian yang menjadi patokan pencapaian kinerja perusahaan sebesar 10,9807\%. Besarnya rasio tersebut adalah lebih tinggi dari rasionet profit margin PT. Dharma Samudera Fishing Industries Tbk tetapi lebih rendah dari rasionet profit margin PT. Astra Agro Lestari Tbk dan PT. Bisi International Tbk.

Standar deviasi rasio net profit margin PT. Astra Agro Lestari Tbk $(5,91873 \%)$ lebih tinggi dari rasio perusahaan lainnya tetapi lebih rendah dari standar deviasi industri $(7,21935 \%)$. Dengan demikian rasio net profit margin industri lebih bervariasi dari rasio perusahaan.

\section{Hasil Uji Normalitas Data}

Tabel berikut ini menyajikan hasil uji normalitas data sampel penelitian pada periode pengamatan. 
Tabel 4. Hasil Uji Normalitas Data

\begin{tabular}{lccr}
\hline \multicolumn{3}{c}{ Saphiro-Wilk } \\
\hline & Statistic & Df & Sig. \\
ROA & 0,946 & 15 & 0,458 \\
ROE & 0,903 & 15 & 0,106 \\
NPM & 0,844 & 15 & 0,014
\end{tabular}

Uji normalitas data menghasilkan nilai Sig. variabel return on asset sebesar 0,458 dan return on equity sebesar 0,106 sedangkan nilai Sig. variabel net profit margin sebesar 0,014. Nilai Sig variabel return on asset dan return on equity lebih besar dari $\alpha=0,05$ sehingga data variabel return on asset dan return on equity dikatakan berdistribusi normal sedangkan data nilai Sig. variabel net profit margin lebih kecil dari $\alpha=0,05$ sehingga data variabel net profit margin dikatakan tidak berdistribusi normal.

\section{Hasil Uji Hipotesis}

\section{Uji Hipotesis I}

Hipotesis I yaitu rata-rata rasio return on asset pada perusahaan-perusahaan yang tergabung dalam Sektor Pertanian di Bursa Efek Indonesia berbeda secara signifikan, diuji dengan melakukan uji homogenitas varian dengan Levene's test terlebih dahulu.

\section{Tabel 5. Hasil Uji Homogenitas Varian.}

ROA

Test of Homogeneity of Variances

\begin{tabular}{|c|c|c|c|}
\hline Levene & df1 & $\mathrm{df} 2$ & Sig. \\
\hline 4,009 & 2 & 12 & 0,046 \\
\hline
\end{tabular}

Uji homogenitas varian menghasilkan nilai Sig. sebesar 0,046 atau lebih kecil dari $\alpha=0,05$. Dengan demikian dapat disimpulkan varian data adalah tidak sama sehingga pengujian hipotesis I dilanjutkan dengan uji Brown-Forsythe.

Tabel 6. Hasil Uji Hipotesis I Dengan Uji Brown-Forsythe. Robust Test of Equality of Means ROA

\begin{tabular}{lcccc}
\hline & Statistic & df 1 & df2 & Sig. \\
\hline Brown-Forsythe & 5,570 & 2 & 5,196 & 0,051 \\
\hline
\end{tabular}

Uji hipotesis I dengan uji Brown-Forsythe menghasilkan nilai Sig. sebesar 0,051 atau lebih besar dari $\alpha=0,005$. Dengan demikian dapat disimpulkan hipotesis nol ditolak 
dan hipotesis alternatif diterima atau rata-rata rasio return on asset pada perusahaanperusahaan yang tergabung dalam Sektor Pertanian di Bursa Efek Indonesia berbeda secara signifikan.

\section{Uji Hipotesis II}

Hipotesis II yaitu rata-rata rasio return on equity pada perusahaan-perusahaan yang tergabung dalam Sektor Pertanian di Bursa Efek Indonesia berbeda secara signifikan, diuji dengan melakukan uji homogenitas varian dengan Levene's test terlebih dahulu.

Tabel7. Hasil Uji Homogenitas Varian.

ROE

Test of Homogeneity of Variances

\begin{tabular}{|c|c|c|c|}
\hline Levene & df1 & df2 & Sig. \\
\hline 4,351 & 2 & 12 & 0,038 \\
\hline
\end{tabular}

Uji homogenitas varian menghasilkan nilai Sig. sebesar 0,038 atau lebih kecil dari $\alpha=0,05$. Dengan demikian dapat disimpulkan varian data adalah tidak sama sehingga pengujian hipotesis II dilanjutkan dengan uji Brown-Forsythe.

Tabel 8. Hasil Uji Hipotesis II Dengan Uji Brown-Forsythe. Robust Test of Equality of Means

ROE

\begin{tabular}{lccccc}
\hline & Statistic & df 1 & df2 & Sig. \\
\hline Brown-Forsythe & 3,236 & & 2 & 6,190 & 0,109 \\
\hline
\end{tabular}

Uji hipotesis II dengan uji Brown-Forsythe menghasilkan nilai Sig. sebesar 0,109 atau lebih besar dari $\alpha=0,051$. Dengan demikian dapat disimpulkan hipotesis nol ditolak dan hipotesis alternatif diterima atau rata-rata rasio return on equity pada perusahaanperusahaan yang tergabung dalam Sektor Pertanian di Bursa Efek Indonesia berbeda secara signifikan.

\section{Uji Hipotesis III}

Hipotesis III yaitu rata-rata rasio net profit margin pada perusahaan-perusahaan yang tergabung dalam Sektor Pertanian di Bursa Efek Indonesia berbeda secara signifikan, diuji dengan melakukan dengan uji Kruskal-Wallis yang merupakan statistik non parametrik karena data tidak berdistribusi normal. 
Tabel 9. Hasil Uji Hipotesis Dengan Uji Kruskal-Wallis.

Kruskal-Wallis Test

Test Statistics

\begin{tabular}{lr}
\hline & NPM \\
\hline Chi Square & 9,420 \\
Df & 2 \\
Assym. Sig. & 0,009 \\
\hline
\end{tabular}

Uji hipotesis III dengan uji Kruskal-Wallis menghasilkan nilai Sig. sebesar 0,009 atau lebih kecil dari $\alpha=0,051$. Dengan demikian dapat disimpulkan hipotesis nol diterima atau rata-rata rasio net profit margin pada perusahaan-perusahaan yang tergabung dalam Sektor Pertanian di Bursa Efek Indonesia berbeda secara tidak signifikan.

\section{Pembahasan}

Tingkat profitabilitas yang tinggi menjadi daya tarik perusahaan bagi investor sehingga saham perusahaan tersebut lebih dipilih karena investor mengharapkan capital gain dan dividen yang tinggi. Kondisi tersebut akan meningkatkan harga saham di pasar modal.

Tingkat profitabilitas dengan rasio return on asset, return on equity dan net profit margin sebagai pencerminan kinerja keuangan yang paling baik dari Sektor Pertanian di Bursa Efek Indoensia adalah PT. Astra Agro Lestari Tbk. Dengan demikian perusahaan tersebut memiliki daya tarik bagi investor dan menjadi patokan pencapaian kinerja perusahaan lainnya dalam sektor tersebut. Saham PT. Astra Agro Lestari Tbk merupakan saham yang cukup diminati investor karena termasuk saham blue-chip. Saham PT. Astra Agro Lestari Tbk selalu terdaftar dalam Indeks LQ45 BEI selama periode pengamatan. Indeks LQ45 merupakan kumpulan saham likuid yang paling banyak diperdagangkan dengan salah satu kriterianya adalah merupakan urutan tertinggi kapitalisasi pasar yang mewakili sektor usahanya.

Uji hipotesis mengenai adanya perbedaan tingkat profitabilitas dengan rasio return on asset, return on equity dan net profit margin pada sampel penelitian konsisten dengan hasil penelitian Asyikin dan Tanu (2011) yang menyatakan terdapat perbedaan kinerja keuangan baik rasio return on assetmaupun return on equity tetapi hasilnya tidak konsisten pada rasio net profit margin. Uji hipotesis dengan kesimpulan rata-rata baik rasio return on assetmaupun return on equitypada perusahaan-perusahaan yang 
tergabung dalam Sektor Pertanian di Bursa Efek Indonesiaberbeda secara signifikan memberikan makna bahwa variabel return on asset dan return on equity dapat memberikan kontribusi sebagai pembeda tingkat profitabilitas karena dapat menunjukkan perbedaan yang signifikan pada perusahaan-perusahaan yang tergabung dalam Sektor Pertanian di Bursa Efek Indonesia.Sebaliknya, uji hipotesis III dengan kesimpulan ratarata rasio net profit margin pada perusahaan-perusahaan yang tergabung dalam Sektor Pertanian di Bursa Efek Indonesia berbeda secara tidak signifikan memberikan makna bahwa variabel net profit margin tidak signifikan dalam memberikan kontribusi sebagai pembeda tingkat profitabilitas pada perusahaan-perusahaan yang tergabung dalam Sektor Pertanian di Bursa Efek Indonesia.

\section{SMPULAN DAN SARAN}

Simpulan dari penelitian ini adalah 1)kinerja keuangan yang terbaik berdasarkan tingkat profitabilitas dengan rasio return on asset, return on equity dan net profit margin pada Sektor Pertanian di Bursa Efek Indonesia adalah PT. Astra Agro Lestari Tbk dibandingkan dengan perusahaan lainnya 2) rata-rata rasio return on asset pada perusahaan-perusahaan yang tergabung dalam Sektor Pertanian di Bursa Efek Indonesia berbeda secara signifikan 3)rata-rata rasio return on equity pada perusahaan-perusahaan yang tergabung dalam Sektor Pertanian di Bursa Efek Indonesia berbeda secara signifikan 4)rata-rata rasio net profit margin pada perusahaan-perusahaan yang tergabung dalam Sektor Pertanian di Bursa Efek Indonesia berbeda secara tidak signifikan.

Berdasarkan hasil penelitian, maka saran-saran yang dapat dikemukakan adalah 1)hendaknya perusahaan dapat mempertahankan dan meningkatkan lagi kemampuannya dalam efektivitas pengelolaan aset, efisiensi pengelolaan modal dan produktivitas dalam penjualan sehingga perusahaan dapat mencapai tingkat profitabilitas yang bertumbuh positif dan berkelanjutan 2)saham yang menjadi pilihan investor adalah saham yang memberikan rasio profitabilitas (return on asset, return on equity dan net profit margin) yang tinggi sehingga rasio return on asset dan return on equitydapat dijadikan indikator bagi investor dalam memilih saham dari Sektor Pertanian Bursa Efek Indonesia karena kedua rasio tersebut memiliki perbedaan rata-rata secara signifikan. 


\section{DAFTAR PUSTAKA}

Asyikin, Jumirin dan Veronica Suryanti Tanu. 2011. Analisa Perbandingan Kinerja Keuangan Perusahaan Farmasi Milik Pemerintah (BUMN) dengan Swasta yang Terdaftar di Bursa Efek Indonesia. Jurnal Spread. Volume 1 Nomor 1 April 2011 Halaman 36-48

Fahmi, Irham. 2011. Analisa Laporan Keuangan. Bandung. Alfabeta

Harahap, Sofyan Syafri. 2011. Analisis Kritis Atas Laporan Keuangan. Jakarta: Raja Grafindo Persada

Husnan, Suad. 2009. Dasar-Dasar Teori Portofolio \& Analisis Sekuritas. Yogyakarta:UPP STIM YKPN

Jumingan. 2011. Analisa Laporan Keuangan. Jakarta:Bumi Aksara

Kasmir. 2012. Analisis Laporan Keuangan. Jakarta:Raja Grafindo Persada

Martalena dan Maya Malinda. 2011. Pengantar Pasar Modal.Yogyakarta:Andi

Munawir, S. 2010. Analisis Laporan Keuangan. Yogyakarta: Liberty

Prihadi,Toto.2010. 7 Deteksi Cepat Kondisi Keuangan:Analisis Rasio Keuangan. Jakarta:PPM

Rhamadana, Recly Bima dan Triyonowati. 2016. Analisis Rasio Keuangan untuk Menilai Kinerja Keuangan pada PT. HM. Sampoerna Tbk. Jurnal Ilmu dan Riset Manajemen. ISSN : 2461-0593. Volume 5 Nomor 7 Juli 2016. Halaman 1-18

Rudianto. 2013. Akuntansi Manajemen Informasi untuk Pengambilan Keputusan Strategis. Jakarta:Erlangga

Sartono, R. Agus. 2010. Manajemen Keuangan Teori \& Aplikasi Yogyakarta: BPFE Sutrisno. 2007. Manajemen Keuangan. Yogyakarta:Ekonesia

Zulkifli dan Dyah Wujayanti. 2014. Analisis Perbandingan Rasio Profitabilitas Perusahaan Penanaman Modal; Asing dan Penanaman Modal Dalam Negeri pada Perusahaan Manufaktur yang Terdaftar di Bursa Efek Indonesia. Jurnal Kajian Bisnis. Volume 22 Nomor 1 Halaman 11-20 